\title{
ChemComm
}

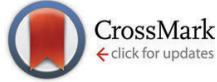

Cite this: Chem. Commun., 2014, 50, 15002

Received 25th September 2014, Accepted 14th October 2014

DOI: $10.1039 / c 4 c c 07582 j$

www.rsc.org/chemcomm

\section{Circular serendipity: in situ ligand transformation for the self-assembly of an hexadecametallic $\left[\mathrm{Cu}^{\prime \prime}{ }_{16}\right]$ wheel $\dagger$}

\author{
Andreas K. Kostopoulos, ${ }^{a}$ Athanassios D. Katsenis, ${ }^{a}$ Jamie M. Frost, ${ }^{b}$ \\ Vadim G. Kessler, ${ }^{\mathrm{C}}$ Euan K. Brechin ${ }^{\star b}$ and Giannis S. Papaefstathiou*a
}

A $\left[\mathrm{Cu}^{\prime \prime}{ }_{16}\right]$ wheel was isolated serendipitously from the reaction of acetylacetone dioxime with copper(II) chloride and lanthanide ions in a reaction initially designed to produce heterometallic $3 d-4 f$ cages. The ligand has been transformed in situ to three different forms, all found within the $\left[\mathrm{Cu}_{16}\right]$ wheel, with the original ligand completely absent.

Synthetic methodologies for the construction of polymetallic cages of paramagnetic metal ions have (rightly) always spanned the entire spectrum from serendipity to designed assembly. ${ }^{1}$ There is clear method in the madness of the former approach: the choice of metal dictates the nature of the magnetic properties of the resulting cluster, and careful thought is exercised in ligand design so that metal ions of a particular type, oxidation state and geometry can be linked in a particular fashion. It is the flexibility in the coordination of both metal and ligand, and the presence of (templating) hydroxide or oxide ions, that renders absolute structure prediction difficult, even if the building blocks - the small fragments dictating topology - are known. Perhaps it is this serendipity that often sees beautiful and novel structural types remaining unreferenced by those outside the community, but the sheer variety and aesthetically pleasing nature of these molecules - beyond the imagination of the humble scientist - is undeniable and reason enough to justify the approach. Such examples include, but are not limited to, the spectacular $\left[\mathrm{Mn}_{84}\right]$ torus, ${ }^{2}$ the $\left[\mathrm{Mn}_{32}\right]$ double-decker wheel, ${ }^{3}$ the $\left[\mathrm{Fe}_{17}\right]$ all-ferric analogue of magnetite obtained from the simple dissolution of $\mathrm{FeBr}_{3}$ in wet pyridine, ${ }^{4}$ the chiral $\left[\mathrm{Er}_{60}\right]^{5}$ stabilized by eight $\mu_{6}-\mathrm{CO}_{3}^{2-}$ ions derived from ligand decomposition, the giant

\footnotetext{
${ }^{a}$ Laboratory of Inorganic Chemistry, Department of Chemistry, National and Kapodistrian University of Athens, Panepistimiopolis, 15771 Zografou, Greece. E-mail: gspapaef@chem.uoa.gr; Fax: +30 210727 4782; Tel: +30 2107274840 ${ }^{b}$ EaStCHEM School of Chemistry, The University of Edinburgh, David Brewster Road, Edinburgh, EH9 3FJ, UK. E-mail: ebrechin@staffmail.ed.ac.uk; Fax: +44 (o)11 275 4598; Tel: +44 (0)131 6507545

${ }^{c}$ Department of Chemistry, Swedish University of Agricultural Sciences, Box 7015, 75007 Uppsala, Sweden

$\dagger$ Electronic supplementary information (ESI) available: CIF files of complexes 1 and 2, experimental data and tables. CCDC 1026037 and 1026038. For ESI and crystallographic data in CIF or other electronic format see DOI: 10.1039/c4cc07582j
}

$\left[\mathrm{Cu}_{17} \mathrm{Mn}_{28}\right]^{6}$ cage comprising six formates derived from the hydrolysis of the solvent (DMF), the enormous $\left[\mathrm{Fe}_{64}\right]^{7}$ and $\left[\mathrm{Fe}_{168}\right]^{8}$ cubic-shaped cages, the $\left[\mathrm{Fe}_{30}\right]$ icosidodecahedron encapsulated inside a $\left\{\mathrm{Mo}^{\mathrm{VI}}{ }_{72} \mathrm{Fe}^{\mathrm{III}}{ }_{30}\right\} \mathrm{POM}$ - a finite-size version of a Kagomé lattice, ${ }^{9}$ and the $\left[\mathrm{Na}_{4} \mathrm{Mn}_{40}\right]$ and $\left[\mathrm{Mn}_{44}\right]$ loop-of-loops. ${ }^{10}$ Many in the molecular magnetism community would also argue that the most 'magnetically interesting' complexes of recent times also have their origins in serendipity. The structures of the molecular magnets $\mathrm{Mn}_{12}, \mathrm{Fe}_{8}, \mathrm{Fe}_{4}, \mathrm{Ni}_{4}, \mathrm{Mn}_{4}, \mathrm{Mn}_{6}$, and $\mathrm{Cr}_{7} \mathrm{M}$ families (to name but a few) for example, could not have been predicted, but thorough exploitation thereafter has seen many fascinating physical properties uncovered and exploited. ${ }^{11}$

The level of structural control over reaction product(s) is decreased yet further when the ligand(s) undergo(es) in situ metal-assisted transformation(s). Di-2-pyridyl ketone ( $\mathrm{py}_{2} \mathrm{CO}$ ), for example, is known to undergo metal-assisted transformations, with more than ten different forms of $\mathrm{py}_{2} \mathrm{CO}$ having been identified. ${ }^{12}$ In some cases, two different forms of $\mathrm{py}_{2} \mathrm{CO}$ have been found within the same cluster. ${ }^{13}$ Indeed there are a number of polynuclear metal complexes comprising two different forms of a ligand obtained by in situ metal-assisted transformations with the initially used ligand either present ${ }^{14}$ or absent. ${ }^{13,15}$

Herein, we present an example of such serendipity in the form of the first example of a polynuclear metal complex, namely the $\left[\mathrm{Cu}_{16}\left(\mathrm{~L}^{1}\right)_{4}\left(\mathrm{~L}^{2}\right)_{8}\left(\mathrm{~L}^{3}\right)_{8}\right] \cdot 8 \mathrm{H}_{2} \mathrm{O}\left(\mathbf{1} \cdot 8 \mathrm{H}_{2} \mathrm{O}\right) \dagger$ wheel, comprising three different forms of acetylacetone dioxime $\left(\mathrm{acacdoH}_{2}\right.$, Scheme 1), in which the initially employed ligand $\left(\mathrm{acacdoH}_{2}\right)$ is absent. Indeed, our initial idea was to utilize acacdoH ${ }_{2}$ for the synthesis of heterometallic $3 \mathrm{~d}-4 \mathrm{f}$ clusters acting as either SMMs or Magnetic Refrigerants.

To this end, we reacted $\mathrm{CuCl}_{2} \cdot 2 \mathrm{H}_{2} \mathrm{O}$ with acacdoH $\mathrm{H}_{2}$ in EtOH, to obtain a bright, light green solution. If this solution remains undisturbed, bright green X-ray quality single-crystals of $\left[\mathrm{Cu}_{2} \mathrm{Cl}_{4}-\right.$ $\left.\left(\text { acacdoH }{ }_{2}\right)_{2}\right](2) \dagger$ are obtained in $75 \%$ yield; addition of an aqueous solution of $\mathrm{Ln}\left(\mathrm{MeCO}_{2}\right)_{3} \cdot x \mathrm{H}_{2} \mathrm{O}(\mathrm{Ln}=\mathrm{Nd}, \mathrm{Gd}, \mathrm{Er})$ into the above solution followed by gentle heating $\left(\sim 40-50{ }^{\circ} \mathrm{C}\right)$ results in a clear dark green solution. Slow evaporation of the latter affords dark green X-ray quality single-crystals of $1 \cdot 8 \mathrm{H}_{2} \mathrm{O}$ in 
<smiles>CC(=NO)C(C)C(C)=NO</smiles><smiles></smiles><smiles>[M]OC(O[M])(C(C)=[N+]([O-])O)C(C)=[N+](O)O</smiles>

$\left(L^{1}\right)^{2-}$

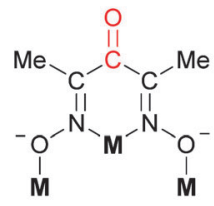

$\left(L^{2}\right)^{2}$

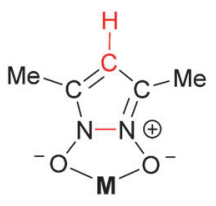

$\left(\mathrm{L}^{3}\right)^{-}$
Scheme 1 Ligands discussed in the text and their coordination modes.

moderate yields (28-37\%, depending on the lanthanide ion). Although the lanthanide ion does not appear in the final product, its presence in the reaction mixture is essential since reactions in its absence do not lead to complex 1. Addition of $\mathrm{H}_{2} \mathrm{O}$ or aqueous solutions of $\mathrm{MeCO}_{2} \mathrm{M} \cdot x \mathrm{H}_{2} \mathrm{O}\left(\mathrm{M}^{+}=\mathrm{NH}_{4}{ }^{+}, \mathrm{Li}^{+}, \mathrm{Na}^{+}\right.$ or $\left.\mathrm{K}^{+}\right)$or $\mathrm{M}^{\prime}\left(\mathrm{MeCO}_{2}\right)_{2} \cdot x \mathrm{H}_{2} \mathrm{O}\left(\mathrm{M}^{\prime}=\mathrm{Zn}^{\mathrm{II}}, \mathrm{Cu}^{\mathrm{II}}, \mathrm{Ni}^{\mathrm{II}}, \mathrm{Co}^{\mathrm{II}}\right.$ or $\left.\mathrm{Mn}^{\mathrm{II}}\right)$ instead of $\operatorname{Ln}\left(\mathrm{MeCO}_{2}\right)_{3} \cdot x \mathrm{H}_{2} \mathrm{O}$ does not lead to complex 1 .

Complex 2 crystallizes in the monoclinic space group $C 2 / c$. It comprises a $\mathrm{Cu}\left(\mu_{2}-\mathrm{Cl}\right)_{2} \mathrm{Cu}$ core with a $\mathrm{Cu} \cdots \mathrm{Cu}$ separation of $3.608 \AA$ (Fig. 1). The two halves of the dimer are related by a crystallographic two-fold axis. The $\mathrm{Cu}\left(\mu_{2}-\mathrm{Cl}\right)_{2} \mathrm{Cu}$ unit is essentially planar with the $\mathrm{Cu}$ and $\mathrm{Cl}$ ions deviating from the least-squares plane by $0.083 \AA$. The geometry around the $\mathrm{Cu}$ ions is best described as distorted square pyramidal $(\tau=0.17)$. The basal plane contains two cis $\mathrm{N}$ atoms from the acacdoH $\mathrm{H}_{2}$ ligand and two cis $\mathrm{Cl}$ ions, with the apical site occupied by the $\mathrm{Cl} 2$ ion from the other monomer unit. Two intramolecular hydrogen bonds between the

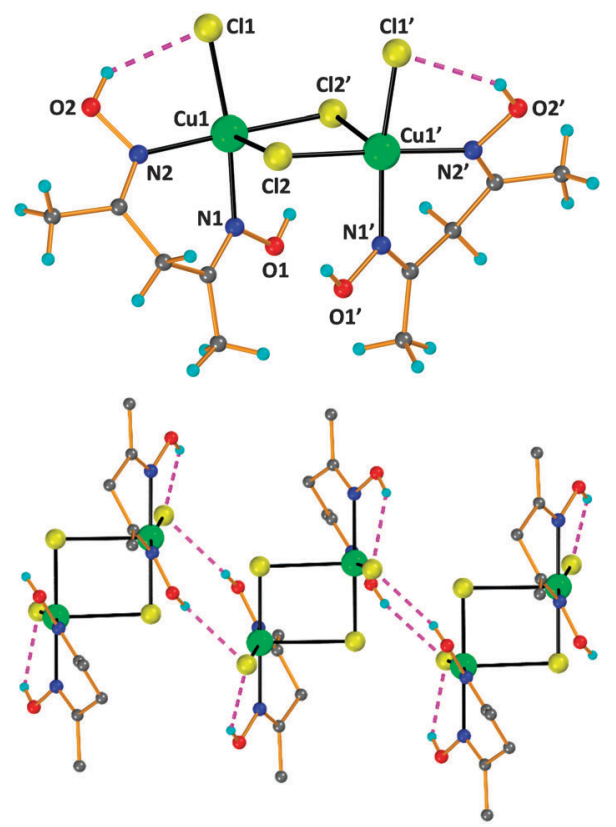

Fig. 1 The structure of 2 (top) and its hydrogen-bonded chain along $c$ (bottom). Most hydrogen atoms have been omitted for clarity. Symmetry code: (') $1-x, y, 1.5-z$. Colour code: $\mathrm{Cu}$ : green, $\mathrm{O}$ : red, $\mathrm{N}$ : blue, $\mathrm{Cl}$ : yellow, C: grey, $\mathrm{H}$ : cyan. oximic $\mathrm{OH}$ groups and the terminal $\mathrm{Cl} 1$ ions stabilize the dimer. The dimers are further hydrogen bonded through the second oximic $\mathrm{OH}$ and the terminal Cl1 ion to form a 1D H-bonded chain along the crystallographic $c$ axis. A salient feature of this structure is that both terminal $\mathrm{Cl}$ ions are on the same side of the $\mathrm{Cu}\left(\mu_{2}-\mathrm{Cl}\right)_{2} \mathrm{Cu}$ plane. Indeed, this is the second example of a molecule in which two terminal $\mathrm{Cl}$ ions in a $\left[\mathrm{LClCu}\left(\mu_{2}-\mathrm{Cl}\right)_{2} \mathrm{CuClL}\right](\mathrm{L}=N, N$-chelate ligand) dimer reside on the same side of the $\left[\mathrm{Cu}_{2}\right]$ plane. ${ }^{16}$

Complex 1 crystallizes in the tetragonal space group P4/nnc. The asymmetric unit comprises two $\mathrm{Cu}$ ions, one $\left(\mathrm{L}^{3}\right)^{-}$, one $\left(\mathrm{L}^{2}\right)^{2-}$ and half a $\left(\mathrm{L}^{1}\right)^{2-}$ ligand (Fig. 2 and Scheme 1$)$. The two $\mathrm{Cu}$ ions ( $\mathrm{Cu} 1$ and $\mathrm{Cu} 2)$ are bridged by one alkoxide $\left(\mathrm{RO}^{-}\right)$and an oximato $\left(\mathrm{N}-\mathrm{O}^{-}\right)$group with a $\mathrm{Cu} \cdots \mathrm{Cu}$ separation of $3.253 \AA$. Two such dimers are related by a crystallographic two-fold axis
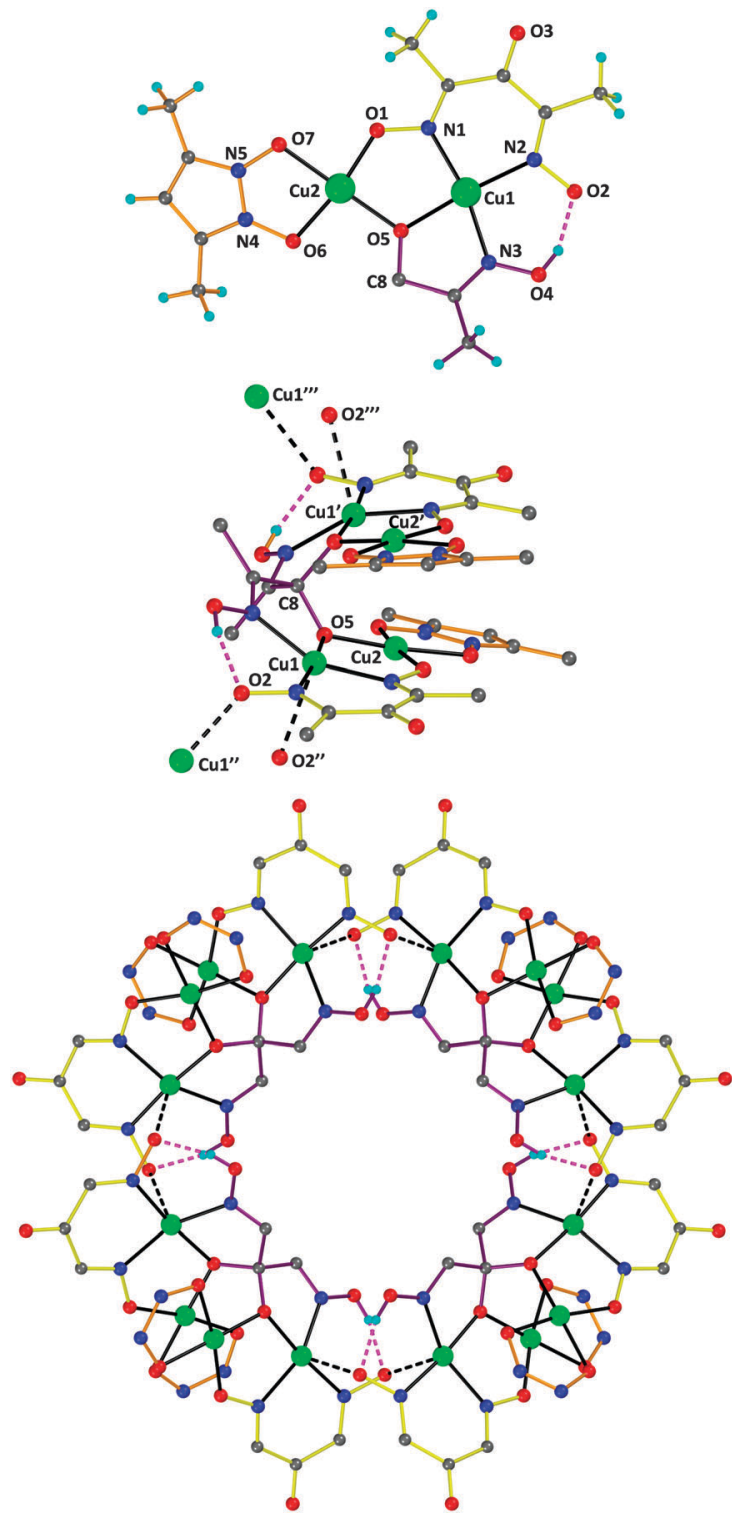

Fig. 2 The asymmetric unit of $\mathbf{1}$ (top), the $\left[\mathrm{Cu}_{4}\right]$ assembly showing the connections to neighbouring $\left[\mathrm{Cu}_{4}\right]$ units (middle) and the $\left[\mathrm{Cu}_{16}\right]$ wheel (bottom). Symmetry codes: (') $0.5-y, 0.5-x, 0.5-z$; (") $1.5-x, y, 0.5-z$; ('"') $0.5-y,-1+x, z$. Colour code: same as in Fig. 1 . 
passing through $\mathrm{C} 8$ of ligand $\left(\mathrm{L}^{1}\right)^{2-}$ to form a tetranuclear assembly with formula $\left[\mathrm{Cu}_{4}\left(\mathrm{~L}^{1}\right)\left(\mathrm{L}^{2}\right)_{2}\left(\mathrm{~L}^{3}\right)_{2}\right]$. Ligand $\left(\mathrm{L}^{1}\right)^{2-}$ which is the hydrate of the oxidized form of acacdoH $\mathrm{H}_{2}$ bridges all $\mathrm{Cu}$ ions within the tetranuclear assembly through the deprotonated hydroxyl groups adopting the $\mu_{4}-\eta^{1}: \eta^{2}: \eta^{2}: \eta^{1}$ coordination mode; the oximic $\mathrm{OH}$ groups remain protonated and are hydrogen bonded to the neighbouring deprotonated oximate $\mathrm{O} 2$ atoms of $\left(\mathrm{L}^{2}\right)^{2-}$ which is the oxidized form of acacdoH $\mathrm{H}_{2}$. The latter, $\left(\mathrm{L}^{2}\right)^{2-}$, chelates Cu1 through the two oximate N1 and N2 atoms and bridges $\mathrm{Cu} 2$ through the deprotonated oximate $\mathrm{O} 1$ atom adopting the $\mu_{2}-\eta^{1}: \eta^{1}: \eta^{1}$ coordination mode. The monoanion $\left(\mathrm{L}^{3}\right)^{-}$simply chelates $\mathrm{Cu} 2$. The second deprotonated oximate $\mathrm{O} 2$ atom of $\left(\mathrm{L}^{2}\right)^{2-}$ is weakly bound to a $\mathrm{Cu} 1$ from a neighbouring tetranuclear assembly $[\mathrm{Cu} 1-\mathrm{O} 2(1.5-x, y, 0.5-z)=2.548 \AA]$ to form the hexadecanuclear wheel $\left[\mathrm{Cu}_{4}\left(\mathrm{~L}^{1}\right)\left(\mathrm{L}^{2}\right)_{2}\left(\mathrm{~L}^{3}\right)_{2}\right]_{4}$. The overall coordination mode of $\left(\mathrm{L}^{2}\right)^{2-}$ is thus $\mu_{3}-\eta^{1}: \eta^{1}: \eta^{1}: \eta^{1}$. The geometry around Cu1 is best described as distorted square pyramidal $(\tau=0.32)$. The basal plane contains two cis $\mathrm{N}$ atoms from the $\left(\mathrm{L}^{2}\right)^{2-}$, the oximic $\mathrm{N} 3$ atom and the $\mathrm{O} 5$ atom from the hydrate $\left(\mathrm{L}^{1}\right)^{2-}$, with the apical site occupied by the oximate $\mathrm{O} 2(1.5-x, y, 0.5-z)$ atom of $\left(\mathrm{L}^{2}\right)^{2-}$ from a neighbouring $\left[\mathrm{Cu}_{4}\right]$. $\mathrm{Cu} 2$ is in a distorted square planar coordination environment, being chelated by two cis $\mathrm{O}$ atoms from $\left(\mathrm{L}^{3}\right)^{-}$, the oximate $\mathrm{O} 1$ atom and the $\mathrm{O} 5$ atom from the hydrate $\left(\mathrm{L}^{1}\right)^{2-}$. In the lattice, the molecules of 1 pack in off-set rows along the $a$ and $b$ axes having their $\left[\mathrm{Cu}_{16}\right]$ mean-planes parallel along the $c$ axis with separations of $8.245 \AA$ and $16.490 \AA$ as shown in Fig. 3. Complex 1 joins a small family of eleven $\left[\mathrm{Cu}^{\mathrm{II}}{ }_{16}\right]$ clusters, ${ }^{17,18}$ three of which are cyclic (wheels or wheel-like). ${ }^{18}$

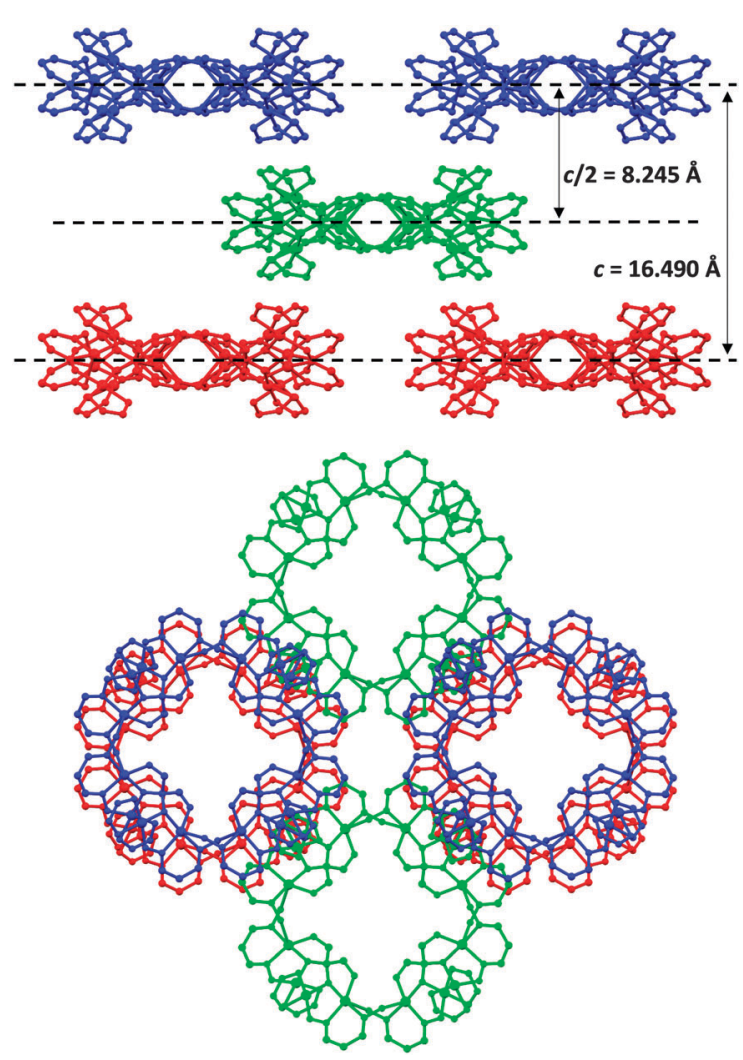

Fig. 3 The packing of complex 1 along a (top) and $c$ (bottom) axes.
Although the transformation of acacdoH $\mathrm{H}_{2}$ to $\left(\mathrm{L}^{1}\right)^{2-},\left(\mathrm{L}^{2}\right)^{2-}$ and $\left(\mathrm{L}^{3}\right)^{-}$was not anticipated, the formation of these anions can be fully rationalized. Methylene moieties $\left(-\mathrm{CH}_{2}-\right)$ attached to electron withdrawing groups can be aerially oxidized to the corresponding ketones with or without the presence of metal ions. ${ }^{19}$ In our case the oxidized form of acacdoH ${ }_{2},\left(\mathrm{~L}^{2}\right)^{2-}$, is probably metal-assisted since the ${ }^{1} \mathrm{H}-\mathrm{NMR}$ spectra of pure acacdoH $\mathrm{H}_{2}$ in $\mathrm{D}_{2} \mathrm{O}$ or $\mathrm{CD}_{3} \mathrm{OD}$ remains unchanged for several months. Ketones, like $\left(\mathrm{L}^{2}\right)^{2-}$ may undergo nucleophilic addition of $\mathrm{H}_{2} \mathrm{O}$ to the carbonyl $\mathrm{C}$ atom to form the respective hydrate, $\left(\mathrm{L}^{1}\right)^{2-}$. The electrophilic character of the carbonyl $\mathrm{C}$ atom may be increased by coordination of the carbonyl $\mathrm{O}$ atom to a metal ion (direct polarization) or by coordination of the oximic $\mathrm{N}$ or $\mathrm{O}$ atoms (induced polarization). Such metal-assisted transformations occur often in $\mathrm{py}_{2} \mathrm{CO}$ chemistry. ${ }^{12,13}$ Alternatively, acacdoH ${ }_{2}$ may first oxidize to the hydrate $\left(\mathrm{H}_{2} \mathrm{~L}^{1}\right)$ which upon dehydration forms the ketone form $\mathrm{H}_{2} \mathrm{~L}^{2}$. Pyrazole $N$-oxides, like $\left(\mathrm{L}^{3}\right)^{-}$, have been previously reported to form by metal-assisted transformations of $\beta$-diketone dioximes. ${ }^{20}$

Dc magnetic susceptibility data for 1 were recorded between 300 and $5 \mathrm{~K}$ in an applied field of $1.0 \mathrm{kG}$. The plots of $\chi_{\mathrm{M}} T$ and $\chi_{\mathrm{M}}$ versus $T$ for 1 are shown in Fig. 4 . The $\chi_{\mathrm{M}} T$ value at $300 \mathrm{~K}$ is $2.87 \mathrm{~cm}^{3} \mathrm{~K} \mathrm{~mol}^{-1}$ and is significantly lower than the expected spin-only $(g=2)$ value for 16 non-interacting $\mathrm{Cu}^{\mathrm{II}}$ centres of $6 \mathrm{~cm}^{3} \mathrm{~K} \mathrm{~mol}^{-1}$, suggesting the presence of dominant and strong antiferromagnetic exchange. The $\chi_{\mathrm{M}} T$ product decreases rapidly upon cooling to a value of $\sim 0.44 \mathrm{~cm}^{3} \mathrm{~K} \mathrm{~mol}^{-1}$ at $100 \mathrm{~K}$ and then decreases smoothly until $5 \mathrm{~K}\left(0.17 \mathrm{~cm}^{3} \mathrm{~K} \mathrm{~mol}^{-1}\right)$. The lowtemperature data denote the presence of $\sim 2.8 \%$ paramagnetic impurity per $\mathrm{Cu}$ ion. Considering the structural parameters a $2-J$ model (inset in Fig. 4) was utilised to fit the experimental data which considers the $\left[\mathrm{Cu}_{16}\right]$ wheel as four weakly interacting $\left[\mathrm{Cu}_{4}\right]$ moieties (the magnetic $\mathrm{d}_{x^{2}-y^{2}}$ orbitals of $\mathrm{Cu} 1$ and $\mathrm{Cu} 1^{\prime \prime}$ belonging to neighbouring $\left[\mathrm{Cu}_{4}\right]$ units being approximately parallel to each other). ${ }^{21}$ In this model, $J_{1}$ denotes the exchange pathway between the $\mathrm{Cu}^{\mathrm{II}}$ ions ( $\left.\mathrm{Cu} 1 \cdots \mathrm{Cu} 2\right)$ bridged by one alkoxide $\left(\mathrm{RO}^{-}\right)$and an oximato $\left(\mathrm{N}-\mathrm{O}^{-}\right)$group, and $J_{2}$ the exchange pathways between

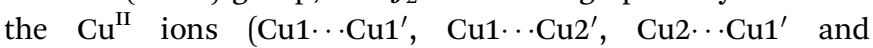
$\left.\mathrm{Cu} 2 \cdots \mathrm{Cu} 2^{\prime}\right)$ bridged by the $\left(\mathrm{CO}_{2}\right)$ moiety of the hydrate $\left(\mathrm{L}^{1}\right)^{2-}$.

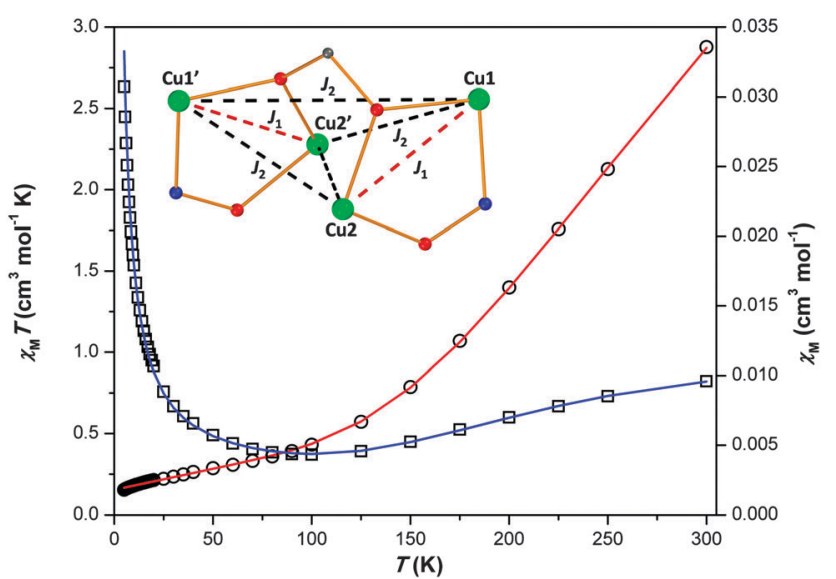

Fig. $4 \chi_{M} T(O)$ and $\chi_{M}(\square)$ vs. $T$ plots for complex 1 . The solid lines represent the best fits of the experimental data - see text for details. 
The experimental data were satisfactorily fitted using the program $\mathrm{PHI}^{22}$ employing the spin Hamiltonian in eqn (1). The best fit (solid lines in Fig. 4) gave the following parameters: $J_{1}=-241.88 \mathrm{~cm}^{-1}$, $J_{2}=-3.42 \mathrm{~cm}^{-1}, g=2.18, z J=-0.027 \mathrm{~cm}^{-1}$, and an impurity $=0.1$ (i.e. $2.5 \%$ per $\mathrm{Cu}$ atom) ( $z J$ describes the intermolecular interactions in a mean field approximation). For such a $\left[\mathrm{Cu}_{4}\right]$ model this results in a spin ground state $S=0$, with the first excited state $(S=1)$ located $\sim 483 \mathrm{~cm}^{-1}$ above the ground state. The large difference in the magnitude of $J_{1}$ and $J_{2}$ is expected: the former describes a one alkoxo, one oximato bridge which is known to provide very effective superexchange, ${ }^{23}$ while the latter is a three atom exchange pathway (Cu-O-C-O-Cu) mediated by the hydrate moiety known to mediate weak exchange. ${ }^{24}$

$\hat{H}_{\mathrm{ex}}=-2 J_{1}\left(\hat{S}_{1} \cdot \hat{S}_{2}+\hat{S}_{3} \cdot \hat{S}_{4}\right)-2 J_{2}\left(\hat{S}_{1} \cdot \hat{S}_{3}+\hat{S}_{1} \cdot \hat{S}_{4}+\hat{S}_{2} \cdot \hat{S}_{3}+\hat{S}_{2} \cdot \hat{S}_{4}\right)$

Our initial forays into the use of acetylacetone dioxime $\left(\right.$ acacdoH $\left.{ }_{2}\right)$ as a ligand for the synthesis of polynuclear metal complexes has afforded a dinuclear $\mathrm{Cu}^{\mathrm{II}}$ complex and an aesthetically pleasing hexadecanuclear $\mathrm{Cu}^{\mathrm{II}}$ wheel. The acacdoH $\mathrm{H}_{2}$ ligand has been transformed into three different species, all of which are found within the wheel. To the best of our knowledge, the $\left[\mathrm{Cu}_{16}\right]$ is the first polynuclear metal complex comprising three different forms of a ligand that has undergone metal-assisted transformation, without the originally employed ligand being present in the reaction product. It is becoming apparent that, given the rich reactivity of acacdoH ${ }_{2}{ }^{20}$ this ligand may play a major role in the synthesis of a variety of novel polynuclear metal complexes in the future. Indeed, when comparing the coordination chemistry of acacdoH $\mathrm{H}_{2}$ with that of $\mathrm{py}_{2} \mathrm{CO}$, which has afforded numerous metal-assisted transformations in approximately 40 years of research, ${ }^{12,13}$ it is self-evident that the former has the potential to surpass the cluster-forming ability of the latter.

\section{Notes and references}

1 R. E. P. Winpenny, J. Chem. Soc., Dalton Trans., 2002, 1; V. A. Milway, F. Tuna, A. R. Farrell, L. E. Sharp, S. Parsons and M. Murrie, Angew. Chem., Int. Ed., 2013, 52, 1949 and references cited therein.

2 A. J. Tasiopoulos, A. Vinslava, W. Wernsdorfer, K. A. Abboud and G. Christou, Angew. Chem., Int. Ed., 2004, 43, 2117.

3 M. Manoli, R. Inglis, M. J. Manos, V. Nastopoulos, W. Wernsdorfer, E. K. Brechin and A. J. Tasiopoulos, Angew. Chem., Int. Ed., 2011, 50, 4441. 4 G. W. Powell, H. N. Lancashire, E. K. Brechin, D. Collison, S. L. Heath, T. Mallah and W. Wernsdorfer, Angew. Chem., Int. Ed., 2004, 43, 5772.

5 X. J. Kong, Y. Wu, L. S. Long, L. S. Zheng and Z. Zheng, J. Am. Chem. Soc., 2009, 131, 6918.

6 W. G. Wang, A. J. Zhou, W. X. Zhang, M. L. Tong, X. M. Chen, M. Nakano, C. C. Beedle and D. N. Hendrickson, J. Am. Chem. Soc., 2007, 129, 1014.

7 T. Liu, Y. J. Zhang, Z. M. Wang and S. Gao, J. Am. Chem. Soc., 2008, 130, 10500.

8 Z. M. Zhang, S. Yao, Y. G. Li, R. Clerac, Y. Lu, Z. M. Su and E. B. Wang, J. Am. Chem. Soc., 2009, 131, 14600.

9 A. Müller, E. Krickemeyer, S. K. Das, P. Kögerler, S. Sarkar, H. Bögge, M. Schmidtmann and S. Sarkar, Angew. Chem., Int. Ed., 2000, 39, 1612.

10 E. E. Moushi, C. Lampropoulos, W. Wernsdorfer, V. Nastopoulos, G. Christou and A. J. Tasiopoulos, J. Am. Chem. Soc., 2010, 132, 16146.
11 W. Wernsdorfer and R. Sessoli, Science, 1999, 284, 133; R. Sessoli and D. Gatteschi, Angew. Chem., Int. Ed., 2003, 42, 268; J. Liu and S. Hill, Polyhedron, 2013, 66, 147; G. Aromi and E. K. Brechin, Struct. Bonding, 2006, 122, 1; M. Affronte, S. Carretta, G. A. Timco and R. E. Winpenny, Chem. Commun., 2007, 1789; S. Hill, R. S. Edwards, N. Aliaga-Alcalde and G. Christou, Science, 2003, 302, 1015-1018; C. J. Milios, R. Inglis, A. Vinslava, R. Bagai, W. Wernsdorfer, S. Parsons, S. P. Perlepes, G. Christou and E. K. Brechin, J. Am. Chem. Soc., 2007, 129, 12505; C. J. Milios and R. E. Winpenny, Struct. Bonding, 2014, DOI: 10.1007/430_2014_149; J.-D. Leng, J.-L. Liu and M.-L. Tong, Chem. Commun., 2012, 48, 5286; Z.-M. Zhang, L.-Y. Pan, W.-Q. Lin, J.-D. Leng, F.-S. Guo, Y.-C. Chen, J.-L. Liu and M.-L. Tong, Chem. Commun., 2013, 49, 8081; J.-L. Liu, W.-Q. Lin, Y.-C. Chen, S. Gómez-Coca, D. Aravena, E. Ruiz, J.-D. Leng and M.-L. Tong, Chem. - Eur. J., 2013, 19, 17567.

12 G. S. Papaefstathiou and S. P. Perlepes, Comments Inorg. Chem., 2002, 23, 249; A. J. Tasiopoulos and S. P. Perlepes, Dalton Trans., $2008,5537$.

13 A. D. Katsenis, V. G. Kessler and G. S. Papaefstathiou, Dalton Trans., 2011, 40, 4590; G. S. Papaefstathiou, A. Escuer, C. P. Raptopoulou, A. Terzis, S. P. Perlepes and R. Vicente, Eur. J. Inorg. Chem., 2001, 1567; A. Dimitrakopoulou, V. Psycharis, C. P. Raptopoulou, A. Terzis, V. Tangoulis and D. P. Kessissoglou, Inorg. Chem., 2008, 47, 7608.

14 K. N. Lazarou, A. K. Boudalis, V. Psycharis and C. P. Raptopoulou, Inorg. Chim. Acta, 2011, 370, 50.

15 M. U. Anwar, Y. Lan, L. M. Beltran, R. Clerac, S. Pfirrmann, C. E. Anson and A. K. Powell, Inorg. Chem., 2009, 48, 5177; Y. F. Zeng, X. Hu, L. Xue, S. J. Liu, T. L. Hu and X. H. Bu, Inorg. Chem., 2012, 51, 9571; J. L. Liu, Y. C. Chen, Q. W. Li, S. Gomez-Coca, D. Aravena, E. Ruiz, W. Q. Lin, J. D. Leng and M. L. Tong, Chem. Commun., 2013, 49, 6549.

16 O. González Q, A. M. Atria, E. Spodine, J. Manzur and M. T. Garland, Acta Crystallogr., Sect. C: Cryst. Struct. Commun., 1993, 49, 1589.

17 T. Sugiura, H. Yoshikawa and K. Awaga, Inorg. Chem., 2006, 45, 7584; L. N. Dawe and L. K. Thompson, Angew. Chem., Int. Ed., 2007, 46, 7440; V. Chandrasekhar and L. Nagarajan, Dalton Trans., 2009, 6712; L. N. Dawe, K. V. Shuvaev and L. K. Thompson, Inorg. Chem., 2009, 48, 3323; T. F. Liu, T. C. Stamatatos, K. A. Abboud and G. Christou, Dalton Trans., 2010, 39, 3554; N. V. Zauzolkova, M. E. Nikiforova, A. A. Sidorov, I. A. Apolonskaya, M. V. Fedin, V. V. Minin, A. V. Rotov, E. A. Ugolkova, M. A. Kiskin, G. G. Aleksandrov, V. M. Novotortsev and I. L. Eremenko, Izv. Akad. Nauk SSSR, Ser. Khim., 2010, 1161; A. Adhikary, S. Goswami, J. A. Sheikh and S. Konar, Eur. J. Inorg. Chem., 2014, 963.

18 P. Klufers and J. Schuhmacher, Angew. Chem., Int. Ed., 1995, 34, 2119; Y. L. Bai, V. Tangoulis, R. B. Huang, L. S. Zheng and J. Tao, Chem. - Eur. J., 2009, 15, 2377; G. A. Craig, M. Schutze, D. Aguila, O. Roubeau, J. Ribas-Arino, S. Vela, S. J. Teat and G. Aromi, Inorg. Chem., 2014, 53, 3290.

19 H.-C. Yao, M.-M. Li, G.-S. Yang, Z.-J. Li and Y. Zhu, Inorg. Chim. Acta, 2007, 360, 3959; F. d. S. Miranda, F. G. Menezes, J. Vicente, A. J. Bortoluzzi, C. Zucco, A. Neves and N. S. Gonçalves, J. Mol. Struct., 2009, 938, 1; J. Zhang, Z. Zhang, Z. Chen and X. Zhou, Dalton Trans., 2012, 41, 357.

20 A. Kotali and V. P. Papageorgiou, Org. Prep. Proced. Int., 1991, 23, 593.

21 R. Ruiz, F. Lloret, M. Julve, J. Faus, M. C. Munoz and X. Solans, Inorg. Chim. Acta, 1998, 268, 263.

22 N. F. Chilton, R. P. Anderson, L. D. Turner, A. Soncini and K. S. Murray, J. Comput. Chem., 2013, 34, 1164.

23 F. Birkelbach, M. Winter, U. Floerke, H.-J. Haupt, C. Butzlaff, M. Lengen, E. Bill, A. X. Trautwein, K. Wieghardt and P. Chaudhuri, Inorg. Chem., 1994, 33, 3990; A. Escuer, M. S. El Fallah, R. Vicente, N. Sanz, M. FontBardia, X. Solans and F. A. Mautner, Dalton Trans., 2004, 1867; A. S. R. Chesman, D. R. Turner, B. Moubaraki, K. S. Murray, G. B. Deacon and S. R. Batten, Eur. J. Inorg. Chem., 2010, 59.

24 A. Chakraborty, B. K. Ghosh, J. Ribas-Arino, J. Ribas and T. K. Maji, Inorg. Chem., 2012, 51, 6440. 